\title{
1 Ammonia at Blodgett Forest, Sierra Nevada, USA
}

3 Marc L. Fischer and David Littlejohn

4

5 Environmental Energy Technologies Division, E.O. Lawrence Berkeley National Laboratory,

61 Cyclotron Rd., Berkeley CA, 94720, USA

7

8 Corresponding author address:

10 Marc L. Fischer, Staff Scientist

11 Atmospheric Sciences Department

12 Mail Stop 90K-125

13 E.O. Lawrence Berkeley National Laboratory

141 Cyclotron Rd.

15 Berkeley, CA 94720-8108

16

17 Phone: 510-486-5539

18 email: mlfischer@lbl.gov 


\section{Abstract}

20 Ammonia is a reactive trace gas that is emitted in large quantities by animal agriculture and other

21 sources in California, which subsequently forms aerosol particulate matter, potentially affecting

22 visibility, climate, and human health. We performed initial measurements of $\mathrm{NH}_{3}$ at the Blodgett

23 Forest Research Station (BFRS) during a two week study in June, 2006. The site is used for

24 ongoing air quality research and is a relatively low-background site in the foothills of the Sierra

25 Nevada. Measured $\mathrm{NH}_{3}$ mixing ratios were quite low ( $<1$ to $\sim 2 \mathrm{ppb}$ ), contrasting with typical

26 conditions in many parts of the Central Valley. Eddy covariance measurements showed $\mathrm{NH}_{3}$

27 fluxes that scaled with measured $\mathrm{NH}_{3}$ mixing ratio and calculated aerodynamic deposition

28 velocity, suggesting dry deposition is a significant loss mechanism for atmospheric $\mathrm{NH}_{3}$ at

29 BFRS. A simple model of $\mathrm{NH}_{3}$ transport to the site supports the hypothesis that $\mathrm{NH}_{3}$ is

30 transported from the Valley to BFRS, but deposits on vegetation during the summer. Further

31 work is necessary to determine whether the results obtained in this study can be generalized to

32 other seasons. 


\section{Introduction}

In California and the nation, many areas are out of compliance with federal particulate matter standards designed to protect human health (NRC 1998; NRC 2000). Nationally, Congress has set a goal to remediate current and prevent future impairment of visibility in over 150 federally designated Class 1 Federal (Malm et al. 2000) designated sites. Ammonia $\left(\mathrm{NH}_{3}\right)$ is the primary gas to form aerosols in combination with acidic species (e.g., $\mathrm{SO}_{\mathrm{X}}, \mathrm{NO}_{\mathrm{X}}$ ) that are produced in combustion processes from energy related activities. While mixing ratios of combustion derived species are regulated, $\mathrm{NH}_{3}$ is not. If ammonia limits aerosol concentrations, then controls on

42 emissions of $\mathrm{NO}_{\mathrm{X}}$ and perhaps $\mathrm{SO}_{\mathrm{X}}$ may not be effective in controlling aerosol concentrations, 43 visibility, or protecting human health.

The magnitude of $\mathrm{NH}_{3}$ fluxes are expected to vary enormously over space. $\mathrm{NH}_{3}$ is emitted from strong point sources (e.g. animal agriculture), medium strength distributed sources (e.g., fertilized fields and automobile catalytic converters), and exchanged with spatially vast areas of soil and vegetation (Potter et al. 2001; Kirchstetter et al. 2002; Battye et al. 2003). Ammonia is of particular interest in California because it is emitted in large amounts from agricultural 50 sources in the Central Valley, leading to high (20-40 ppb) surface layer $\mathrm{NH}_{3}$ mixing ratios 51 (Fischer et al. 2003; Lunden et al. 2003; Chow et al. 2006). For example, recent work suggest 52 that San Joaquin Valley area emissions might range from 8 to $42 \mathrm{~g} \mathrm{~N} \mathrm{ha}^{-1}$ day $^{-1}$ (11 to $50 \mathrm{ng} \mathrm{NH}_{3}$

$53 \mathrm{~m}^{-2} \mathrm{~s}^{-1}$ ) in winter and summer respectively, with approximately $78 \%$ of the summertime

54 emissions derived from animal agriculture (Battye et al. 2003).

56 While most $\mathrm{NH}_{3}$ measurements have been made in urban areas in California, some

57 measurements have been made in rural settings. Airborne measurements in the afternoon mixed

58 layer showed that ammonium compounds (i.e., $\mathrm{NH}_{3}+\mathrm{NH}_{4}{ }^{+}$) were the dominant component of 59 the $\mathrm{N}$ budget with variable $\mathrm{NH}_{3}$ concentrations corresponding to mixing ratios of $10 \pm 7$ and 2.5

$60 \pm 0.5 \mathrm{ppb}$ in boundary layer above the foothills of the Sierra in the boundary layer above Lake

61 Tahoe respectively (Zhang et al. 2002). In contrast, a ground-based study at Lake Tahoe

62 measured significantly lower concentrations corresponding to approximate mixing ratios 
63 between 0.6 to $1.5 \mathrm{ppb}$ and mean summer deposition rates between 3 to $11 \mathrm{ng} \mathrm{N} \mathrm{m} \mathrm{N}^{-2}$ (Tarnay

64 et al. 2001). The previous work raises the question of whether there are vertical gradients in $\mathrm{NH}_{3}$

65 caused by dry deposition or whether the differences in $\mathrm{NH}_{3}$ at the surface and aloft are due to

66 different measurement times.

68 Here we describe a short term study of the $\mathrm{NH}_{3}$ mixing ratios and $\mathrm{NH}_{3}$ fluxes at a rural site in the 69 foothills of the Sierra Nevada.

\section{$71 \quad 2$. Methods}

72 The methods section includes a description of the measurement site, the fast response $\mathrm{NH}_{3}$

73 instrument, the methods used for data reduction, a filter sampling system used to provide

74 comparative $\mathrm{NH}_{3}$ measurements, a method used to calculate the aerodynamic deposition velocity

75 expected under different meteorological conditions, and a predictive model for $\mathrm{NH}_{3}$ mixing

76 ratios at the measurement site.

\section{$77 \quad 2.1$ Measurement Site}

\section{UC Berkeley Blodgett Forest Research Station}

79 We measured $\mathrm{NH}_{3}$ mixing ratios and fluxes near the University of California's Sierra Nevada the 80 Blodgett Forest Research Station (BFRS), located west of the Sacramento region as shown in

81 Figure 1. The BFRS site is an attractive site for this work because it is representative of large 82 areas of forested land with acidic soils in the mountainous Western US and has been the site of 83 ongoing air quality measurements (Goldstein et al. 2000; Dillon et al. 2002; Kurpius et al. 2002; 84 Farmer et al. 2006). Although recent work at BFRS has studied mixing ratios and fluxes of 85 several reactive nitrogen species, $\mathrm{NH}_{3}$ has not been measured previously.

86 The BFRS tower is located at $38.88^{\circ} \mathrm{N}, 120.62^{\circ} \mathrm{W}$, at an elevation of $1315 \mathrm{~m}$ in a re87 growing ponderosa pine plantation. Tree heights ranged from approximately 8-10 m. Terrain is 88 gently sloping downward from east to west. Power to the site is provided by a diesel generator 89 located approximately $130 \mathrm{~m}$ due north of the tower site. The predominant winds are upslope 90 from the southwest during the day and downslope from the northeast during the night.

\section{$91 \quad 2.2 \mathrm{NH}_{3}$ Instrument}


93 Ammonia was measured using a sensitive fast-response quantum-cascade laser (QCL)

94 spectrometer operating at a frequency of $965 \mathrm{~cm}^{-1}$ (Aerodyne Research Inc (ARI), similar to that 95 used for eddy covariance flux measurements of $\mathrm{NO}_{2}$ (Zahniser 2003; Horii et al. 2004). The 96 precision of the $\mathrm{NH}_{3}$ instrument is normally $0.3 \mathrm{ppb}$ (1 sigma) for data collected at a frequency 97 of $10 \mathrm{~Hz}$. The instrument provided highly automated control of high frequency data collection, 98 zero adjustments, and zero and span checks as described below using a dedicated software 99 package (TDLWintel).

101 In addition to the QCL spectrometer, additional data was collected. First, a sonic anemometer 102 (Gill Windmaster Pro) was used to measure fluctuations in virtual air temperature and 3-D 103 winds. The digital output from the anemometer was logged by the computer controlling the 104 QCL spectrometer. The anemometer was physically positioned so that the sensing volume was 105 located $30 \mathrm{~cm}$ from the inlet manifold of the $\mathrm{NH}_{3}$ instrument. Second, a data logger (Campbell 106 CR23X) recorded gas flow rates controlled by mass flow controllers, inlet surface temperatures 107 measured with thermocouples, atmospheric temperature and relative humidity (Vaisala Y45), 108 and short wave solar radiation (Kipp and Zonen CM3).

109

110 The $\mathrm{NH}_{3}$ and ancillary meteorological measurements were made at a height of approximately 10 $111 \mathrm{~m}$ above the ground, sufficient to reach slightly above the nearby vegetation. The combined 112 weight of the spectrometer, support electronics and thermal control system and liquid nitrogen

113 storage dewar for automated refills of the spectrometer detector dewar (total of $\sim 200 \mathrm{~kg}$ )

114 required a platform scissor-lift. The scissor lift was located at a distance of approximately $8 \mathrm{~m}$ 115 from the main BFRS meteorological tower. During the two day period from July 24 to 25, when 116 the LBNL measurements were compared with the filter sampler, the platform was lowered to a 117 height of $\sim 6 \mathrm{~m}$ to match the height of the filter sampler. The filter sampler was deployed on the 118 main BFRS tower.

120 To achieve high temporal resolution necessary for eddy covariance measurements, we designed a 121 high flow rate gas sampling and calibration subsystem that transmits ambient $\mathrm{NH}_{3}$ vapor to the 122 spectrometer with minimal residence time. A schematic of the inlet and calibration system is 
123 shown in Fig. 2. A flow of ambient air is drawn into the sample manifold by the combination of

124 a manifold flow pump (at 20 slpm) and into the $\mathrm{NH}_{3}$ spectrometer at a rate (approximately 25

125 slpm) determined by the pump speed (Varian 600 dry scroll) and the diameter of a critical orifice

126 inlet. After entering the critical orifice (which reduces the pressure to approximately 50 Torr), air

127 is passed through a 0.2 micron PTFE air filter (Gelman PALL, Acro-50), a $2 \mathrm{~m}$ long $1 \mathrm{~cm}$

128 diameter PFA Teflon tube to the multipass optical cell contained within the QCL spectrometer.

129 All glass surfaces are siloxyl coated (General Electric) and surfaces are heated as suggested in

130 Neuman et al (1999). In our application, the temperatures of the different inlet parts were

131 maintained between 40 and $45^{\circ} \mathrm{C}$ by a set of four temperature control circuits, while the optical

132 bench including the optical absorption cell was maintained at $30^{\circ} \mathrm{C}$.

133

134 During the measurements, the instrument zero was adjusted every 30 minutes, under control of

135 the spectrometer computer, by overfilling the inlet manifold with an approximately 60 slpm flow

136 of dry nitrogen supplied by a large liquid $\mathrm{N}_{2}$ supply dewar. Typically, zero adjustments were

137 significantly less than 1 ppb. In addition, the instrument zero and span were checked

138 periodically. Zeros were generally checked every 30 minutes. The span of the instrument was

139 checked by reversing a backflow of $300 \mathrm{sccm}$ that normally removes a $100 \mathrm{sccm}$ flow of $\mathrm{NH}_{3}$

140 supplied from a permeation tube source. After applying $\mathrm{NH}_{3}$ for $30 \mathrm{~s}$, the backflow is

141 reestablished removing $\mathrm{NH}_{3}$ from the inlet. The response time of the instrument to an

142 approximately 15 ppb step in $\mathrm{NH}_{3}$ mixing ratio was checked once each hour by applying a $\mathrm{NH}_{3}$

143 from a permeation tube source to the $\mathrm{N}_{2}$ flow. As shown in Figure 3, the response is well

144 characterized by the sum of exponential decay terms as

$145 \quad \mathrm{NH}_{3}(\mathrm{t})=\mathrm{No}\left(\mathrm{a}_{1} \exp \left(-\mathrm{t} / \tau_{1}\right)+\mathrm{a}_{2} \exp \left(-\mathrm{t} / \tau_{2}\right)\right)$,

146 where a1 $=0.8+/-0.05, \tau_{1}=0.35+/-0.05 \mathrm{~s}, \mathrm{a}_{2}=\left(1-\mathrm{a}_{1}\right)$, and $\tau_{2}=4+/-1 \mathrm{~s}$. The uncertainties in

147 the values reported for the decay coefficients time constants represent variations in the best fit

148 values obtained from fits taken over the experimental period.

\subsection{Data Reduction}

152 The $10 \mathrm{~Hz}$ data $\mathrm{NH}_{3}$ were processed to estimate mean $\mathrm{NH}_{3}$ mixing ratios and $\mathrm{NH}_{3}$ fluxes. For 153 mean $\mathrm{NH}_{3}$, a continuous estimate of instrument zero was estimated as a spline interpolation of 
$154 \mathrm{NH}_{3}$ values obtained during the stable period at the end of zero checks (see Figure 3). The 155 instrument zero was less than $1 \mathrm{ppb}$ for $90 \%$ of the data, until June $21^{\text {st }}$, when the instrument ran 156 out of cryogens. Upon restarting the instrument on June $23^{\text {rd }}$, the instrument noise level had 157 increased by nearly an order of magnitude (to 3 ppb in 1 second integration), leading to a larger 158 variation in zero level. Following subtraction of instrument zeros, mean mixing ratios were 159 calculated for 1 and 12 hour bins.

160

$\mathrm{NH}_{3}$ flux was computed for $1 / 2$ hour intervals from the covariance of the $10 \mathrm{~Hz} \mathrm{NH}$ mixing ratios 162 and the vertical wind using standard techniques (Baldocchi et al. 1988). Wind fields were rotated to a coordinate system with zero mean vertical wind. Fluctuations in ammonia, $\mathrm{NH}_{3}$, virtual temperature, T', and wind vectors, u', v', and w', were calculated by subtracting 1/2 hour

165 block averages. Vertical fluxes were calculated as the covariance between vertical wind 166 fluctuations, w’, and other quantities. Periods during $\mathrm{NH}_{3}$ zero or span measurements were 167 excluded. The mean ammonia flux, $\mathrm{F}_{\mathrm{NH} 3}=\left\langle\mathrm{w}^{\prime} \mathrm{NH}_{3}{ }^{\prime}>\right.$ was estimated for each $1 / 2$ hour interval. 168 The time lag between $\mathrm{w}^{\prime}$ and $\mathrm{NH}_{3}$, required to maximize $\mathrm{F}_{\mathrm{NH} 3}$, was determined from lag 169 correlation plots. Typical values for the best lag were small $(<0.3 \mathrm{~s})$, and roughly consistent 170 with that expected from the measured step response of the inlet system.

172 To correct for loss of high frequency $\mathrm{NH}_{3}$ fluctuations due to finite frequency response of the gas 173 inlet, we applied an empirically derived multiplicative correction (Horii et al. 2004). The 174 correction was computed from the measurements of sensible heat obtained from the sonic 175 anemometer. Here sensible heat is calculated as, $\mathrm{H}=\rho \mathrm{C}_{\mathrm{p}}<\mathrm{w}^{\prime} \mathrm{T}^{\prime}>$, where $\rho$ and $\mathrm{C}_{\mathrm{p}}$ are the 176 density and specific heat of air respectively. We calculated the correction factor, $177 \quad \mathrm{f}_{\text {corr }}=\mathrm{w}^{\prime} \mathrm{T}^{\prime} / \mathrm{w}^{\prime} \mathrm{T}_{\mathrm{sm}}$,

178 where $\mathrm{T}_{\mathrm{sm}}$ ', is obtained by convolving $\mathrm{T}$ ' with the double exponential decay function describing 179 the step response to $\mathrm{NH}_{3}$ span decay in $\mathrm{Eq}(1)$. Typical values for $\mathrm{F}_{\text {corr }}$ ranged from 1 to 1.2 180 depending on the atmospheric stability, indicating that the $\mathrm{NH}_{3}$ captured most of the high 181 frequency fluctuations contributing to the flux. As an additional check of the frequency response, 182 power spectra for w'T', w' $\mathrm{T}_{\mathrm{sm}}$ ', and $\mathrm{w}^{\prime} \mathrm{NH}_{3}$ ' were computed for $1 / 2$ hour periods and compared 183 with the $-4 / 3$ power law expected from Komolgorov similarity theory. 
185 We determined whether the $\mathrm{NH}_{3}$ fluxes were stationary by comparing the $1 / 2$ hour mean flux with 186 the mean of the individual fluxes determined from 5 minute sub-intervals. Data was considered 187 to be stationary when the flux calculated from the subintervals is within $30 \%$ of the $1 / 2$ hour mean 188 flux (Foken et al. 1996). Non-stationary conditions typically occur during periods of intermittent 189 turbulence which typically occurs on nights when the air is stably stratified and friction velocity,

$190 \mathrm{u}^{*}=<-\mathrm{w}^{\prime} \mathrm{u}^{\prime}>^{1 / 2}$ is low $\left(\mathrm{u}^{*}<0.1 \mathrm{~m} \mathrm{~s}^{-1}\right)$. Non-stationary fluxes of nitrogen oxides have also been 191 observed at BFRS, associated with emissions from the generator (Farmer et al. 2006). We 192 excluded the data ( 20\%) obtained when the wind direction was within 45 degrees of north.

\section{$193 \quad 2.4$ Filter Sampling}

194 Ambient $\mathrm{NH}_{3}$ concentrations were determined during a two day period (starting on the evening 195 of June $23^{\text {rd }}$ and continuing into midday of June $25^{\text {th }}$ ) using filter samples collected with the 196 Desert Research Institutes (DRI) sampler (Chow et al. 1993). As described above, the inlet of 197 the filter sampler was located at a height of $5.5 \mathrm{~m}$ off the ground on the main meteorological 198 tower. In this method, two filter samples are collected simultaneously. One filter is exposed to a 199 flow of ambient air, while the other is exposed to air that has had gaseous $\mathrm{NH}_{3}$ removed by an 200 annular denuder. Then the denuded filters collected only particulate $\mathrm{NH}_{4}{ }^{+}$, while the undenuded 201 filter collected both gas and aerosol. Gaseous $\mathrm{NH}_{3}$ is estimated as the difference between 202 undenuded and denuded measurements. In this experiment, four sets of paired (denuded and 203 undenuded) citric acid coated filters were exposed to air flows near 100 liters per minute 204 (measured before and after each sample was collected) over the two day period using 12 hour 205 collection times (1800-0600 and 0600-1800 PDT, or 0100-1300 and 1300-0100 GMT). Before 206 and after sample collection the filters were stored in capped, bagged, and stored in an ice chest. 207 Following collection on June, $25^{\text {th }}$, the samples were returned to DRI for analysis of $\mathrm{NH}_{4}{ }^{+}$ions 208 captured on the citric acid.

\section{$210 \quad 2.5$ Estimate of Maximum Deposition Velocity}

211 As a check on the observed $\mathrm{NH}_{3}$ fluxes, we computed deposition velocities, $\mathrm{V}_{\mathrm{d}}=\mathrm{F}_{\mathrm{NH} 3} / \mathrm{NH}_{3}$, for 212 each $1 / 2$ hour interval and compared it to a simple model for the maximum deposition velocity 213 expected if all $\mathrm{NH}_{3}$ molecules are reaching the leaf surfaces are adsorbed. In general, deposition 214 velocity can be expressed in a resistance based model as, 


$$
\mathrm{V}_{\mathrm{d}}=\left(\mathrm{R}_{\mathrm{a}}+\mathrm{R}_{\mathrm{b}}+\mathrm{R}_{\mathrm{c}}\right)^{-1} \text {, }
$$

216 where $\mathrm{R}_{\mathrm{a}}, \mathrm{R}_{\mathrm{b}}$, and $\mathrm{R}_{\mathrm{c}}$, are the aerodynamic, leaf boundary layer, and stomatal resistances

217 respectively. In the limit that the vegetation is nitrogen limited and readily accepts all $\mathrm{NH}_{3}$

218 reaching the leaf surface, $\mathrm{R}_{\mathrm{c}}$ can be assumed to be small and a maximum deposition velocity can

219 be written as

$$
\mathrm{V}_{\mathrm{dmax}}=\left(\mathrm{R}_{\mathrm{a}}+\mathrm{R}_{\mathrm{b}}\right)^{-1} \text {, }
$$

221 Using standard turbulence models for the surface layer fluxes, one can write a set of expressions 222 for $\mathrm{R}_{\mathrm{a}}$ and $\mathrm{R}_{\mathrm{b}}$ (Wesely 1989; Horii et al. 2004). Here

$223 \quad \mathrm{R}_{\mathrm{a}}=\mathrm{u} / \mathrm{u}^{* 2}-\chi_{\mathrm{H}} /\left(\mathrm{ku}^{*}\right)$,

224 where $\mathrm{k}$ is the Von Karmen coefficient $(\sim 0.4)$. Under stable conditions $\chi_{\mathrm{H}}$ can be expressed as

$225 \quad \chi_{\mathrm{H}}=5(\mathrm{z}-\mathrm{d}) / \mathrm{L}$,

226 where $\mathrm{z}$ is the measurement height, $\mathrm{d}$ is the displacement height (often assumed to be 0.75

227 vegetation height), and $\mathrm{L}$ is the Monin-Obukhov length scale, $\mathrm{L}=-\mathrm{kg}<\mathrm{w}^{\prime} \mathrm{T}^{\prime}>/ \mathrm{Tu}^{*}$, and $\mathrm{g}$ is the 228 acceleration due to Earth’s gravity. Stable conditions are defined as when L > 0. Under unstable 229 conditions $(\mathrm{L}<0)$,

$$
\chi_{\mathrm{H}}=\exp \left(0.598+0.39 * \ln (-(\mathrm{z}-\mathrm{d}) / \mathrm{L})-0.09 *(\ln (-(\mathrm{z}-\mathrm{d}) / \mathrm{L}))^{2}\right) .
$$

231 Finally, the boundary layer resistance at the leaf surface can be written as

$$
\mathrm{R}_{\mathrm{b}}^{-1} \sim \mathrm{u}^{*} / 7.1
$$

233 Under the conditions observed at a mixed deciduous forest in Northeastern United States, Horri

234 et al. (2004) observed $0.01<\mathrm{V}_{\mathrm{d}}<0.08 \mathrm{~m} \mathrm{~s}^{-1}$.

\section{$235 \quad 2.6$ Simulation of $\mathrm{NH}_{3}$ Mixing Ratios}

236 Measured $\mathrm{NH}_{3}$ mixing ratios were compared with simulated $\mathrm{NH}_{3}$ concentrations derived from

237 and a regional emission inventory estimate of $\mathrm{NH}_{3}$ emissions combined with a particle back

238 trajectory calculation of time and space specific surface influence on atmospheric gas

239 concentrations and dry deposition of $\mathrm{NH}_{3}$.

241 A simple $\mathrm{NH}_{3}$ emission model was used for these simulations. $\mathrm{NH}_{3}$ emissions for June were 242 estimated assuming that cows in dairies and feedlots generated a large fraction of the emissions 243 in the Central Valley. The spatial distribution of cows was obtained from county level statistics 244 for 2002 animal stocking density reported by the United States Department of Agriculture’s 
245 National Agricultural Statistics Service (NASS, 2004). We estimated the $\mathrm{NH}_{3}$ emission factors

246 for the summer conditions by scaling the annual averaged emissions factors by the ratio (2.3) of

247 summer time animal fluxes to annually averaged animal fluxes in the San Joaquin Valley (Battye

248 et al. , 2003). The resulting emissions factors are 185 and $64 \mathrm{~g} \mathrm{NH}_{3}$ animal $^{-1}$ day $^{-1}$ for dairy and

249 non-dairy cattle respectively. County level $\mathrm{NH}_{3}$ fluxes were calculated as the total $\mathrm{NH}_{3}$

250 emissions for each county normalized by the area and are shown in Table 1. Fluxes from

251 Nevada were set equal to the $2 \mathrm{ng} \mathrm{m}^{-2} \mathrm{~s}^{-1}$, similar to low emission counties in California. We did

252 not attempt to include other sources of $\mathrm{NH}_{3}$ emission (e.g, other animal agriculture or

253 automobiles) and hence this estimate likely represents a lower limit to $\mathrm{NH}_{3}$ fluxes. However, we

254 consider this simple model roughly sufficient for determining the temporal variations in $\mathrm{NH}_{3}$

255 expected at BFRS, particularly given the additional approximations we make in estimating the

256 transport of $\mathrm{NH}_{3}$ from remote locations to the site.

258 The surface influence functions were calculated using the stochastic time inverted Lagrangian 259 transport (STILT) model (Lin et al. 2003). STILT was originally derived from the NOAA 260 HYSPLIT particle transport model (Draxler et al. 1998) for inverse model estimates of surface $261 \mathrm{CO}_{2}$ fluxes (Lin et al. 2004). In our simulations, ensembles of 100 particles were released from 262 the tower site every 2 hours and run backward in time for a period of 12 hours, which generally 263 allowed the particles to reach locations in the central valley. STILT was driven with NOAA 264 reanalysis meteorology (EDAS40) with $40 \mathrm{~km}$ spatial resolution and hourly temporal resolution.

265 Land surface contributions to atmospheric $\mathrm{NH}_{3}$ were assumed to be proportional to the time a 266 particle spends within the surface boundary layer. $\mathrm{NH}_{3}$ deposition was assumed to depend on the 267 rate of vertical mixing in the atmosphere and parameterized as a residence time $\tau=\mathrm{z} / \mathrm{V}_{\mathrm{d} 0}$, where $268 \mathrm{z}$ is the particle altitude above ground and $\mathrm{V}_{\mathrm{d} 0}=0.02 \mathrm{~m} \mathrm{~s}^{-1}$ is an assumed mean deposition 269 velocity. For each time step, $\Delta \mathrm{t}, \mathrm{NH}_{3}$ is updated as

$270 \quad \mathrm{NH}_{3}(\mathrm{t}+\Delta \mathrm{t})=\mathrm{NH}_{3}(\mathrm{t}) \mathrm{e}^{-\Delta \mathrm{t} / \tau}+\mathrm{F}_{\mathrm{NH} 3} \Delta \mathrm{t} / \mathrm{z}_{\mathrm{i}} \nu$,

271 where $\mathrm{F}_{\mathrm{NH} 3}\left(\mathrm{nmol} \mathrm{m} \mathrm{s}^{-2}\right)$ is the surface $\mathrm{NH}_{3}$ flux at the position of the particle, $\mathrm{z}_{\mathrm{i}}$ is the height of 272 the boundary layer, and $v$ is the molecular density of air. Simulations were run both with and 273 without the deposition loss term to estimate the concentration expected for a non-reacting gas.

274 3. Results and Discussion 


\subsection{Surface $\mathrm{NH}_{3}$ Mixing ratios}

277 Figure 4 shows the hourly averages of measured $\mathrm{NH}_{3}$ from the LBNL laser spectrometer and the 278 mean results from the 12 hour samples collected by the DRI filter system. Both LBNL and DRI

279 data show that $\mathrm{NH}_{3}$ was generally between 0 and $2 \mathrm{ppb}$, with a few periods of higher mixing

280 ratios. Near June $13^{\text {th }}$, a synoptic event introduced cooler air from the north with lower 281 temperatures and mild precipitation, reducing $\mathrm{NH}_{3}$ concentrations significantly. The averages of 282 the LBNL measurements were lower than the filter samples on June $24^{\text {th }}$, and similar to or higher 283 than the filter samples on June, $25^{\text {th }}$ (see Table 2). Inspection of the LBNL data suggests that a 284 significant fraction of the data was noisy and did not pass quality control criteria ( 50\% in some 285 of the 12 hour periods), perhaps causing the poor correlation between LBNL averages and the 286 DRI filter measurements.

We also examined the diurnal variations in $\mathrm{NH}_{3}$. As shown in Figure 5, there was a significant diurnal cycle with lower mixing ratios at night and higher mixing ratios during the day. This is 290 consistent with having predominantly downslope winds carrying $\mathrm{NH}_{3}$ free air from the Sierra 291 Nevada during the night and upslope winds carrying air with $\mathrm{NH}_{3}$ from the Central Valley during 292 the day (Dillon et al. 2002).

\section{3.2 Calculated Aerosol - Gas Equilibrium}

We considered whether the low $\mathrm{NH}_{3}$ mixing ratios might limit ammonium-based aerosol 296 concentrations by comparing measured $\mathrm{NH}_{3}$ with previously measured $\mathrm{HNO}_{3}$ and the aerosol297 gas equilibrium coefficient, Kp, which defines the minimum $\mathrm{NH}_{3} * \mathrm{HNO}_{3}$ product required to 298 form $\mathrm{NH}_{4} \mathrm{NO}_{3}$ aerosol (Stelson et al. 1982). Figure 6 shows that $\mathrm{Kp}>>1 \mathrm{ppb}^{2}$ for most of the 299 observation period. Earlier work at Blodgett showed that $\mathrm{HNO}_{3}$ mixing ratios fell in a range of $300 \quad 0.3$ to $1.5 \mathrm{ppb}$ (5\%-95\%) for June-October (Murphy et al., 2006). Assuming a nominal value of $3011 \mathrm{ppb} \mathrm{HNO}_{3}$, the minimum $\mathrm{NH}_{3}$ mixing ratio required to support aerosol $\mathrm{NH}_{3} * \mathrm{HNO}_{3}$ in 302 equilibrium with gas phase constituents is numerically equal to the value of Kp. Since the 303 measured $\mathrm{NH}_{3}$ mixing ratio is generally significantly less than $\mathrm{Kp}$, this suggests that aerosol $304 \mathrm{NH}_{3}{ }^{*} \mathrm{HNO}_{3}$ will not be present in equilibrium with gases. We also note that although Kp was 
305

low during points earlier in June, there were also light rains, which would likely strip $\mathrm{NH}_{3}$, $\mathrm{HNO}_{3}$, and aerosols from ambient air.

\section{3 $\mathrm{NH}_{3}$ Fluctuations, Fluxes, and Deposition Velocities}

Before computing $\mathrm{NH}_{3}$ fluxes, we examined the power spectra for temporal variations in w'T', w' $\mathrm{T}$ ' sm, and w' $\mathrm{NH}_{3}$ for each $1 / 2$ hour period over which $\mathrm{NH}_{3}$ fluxes were calculated. By comparing the spectra of w' $\mathrm{T}^{\prime}$ and $\mathrm{w}^{\text {' }} \mathrm{T}$ ' ${ }_{\mathrm{sm}}$, we can visually inspect the loss of high frequency power in w' $\mathrm{T}$ ' introduced by smoothing $\mathrm{T}$ ' with the finite frequency response of the $\mathrm{NH}_{3}$ inlet system. A representative set of power spectra are shown in Figure 7. As expected, the spectra for w'T' and w' ${ }^{\prime}$ 'sm are similar, consistent with the smoothing reducing w'T' by a small amount, and suggesting that $\mathrm{NH}_{3}$ fluxes can be accurately recovered. We also note parenthetically that the high frequency slope of all three of the spectra was not as steep as that expected for turbulence in a Komolgorov similarity theory, as observed by other researchers at this and other sites (Farmer et al. 2006).

The $\mathrm{NH}_{3}$ fluxes calculated from the $10 \mathrm{~Hz}$ data are shown in Figure 8. Most of the $\mathrm{NH}_{3}$ fluxes were small ( $10 \mathrm{ng} \mathrm{NH}_{3} \mathrm{~m}^{-2} \mathrm{~s}^{-1}$ ) or negative. During a several day period early in the campaign when $\mathrm{NH}_{3}$ mixing ratios were highest, large negative fluxes (- $\left.30 \mathrm{ng} \mathrm{NH}_{3} \mathrm{~m}^{-2} \mathrm{~s}^{-1}\right)$ were observed, indicating that $\mathrm{NH}_{3}$ was being lost to the canopy by dry deposition. The mean flux during the measurement period was $9.2 \pm 1.1 \mathrm{ng} \mathrm{NH}_{3} \mathrm{~m}^{-2} \mathrm{~s}^{-1}$. As a check of whether the estimated fluxes were realistic, we calculated deposition velocities for a subset of the measured fluxes. The subset was obtained by requiring that the $\mathrm{NH}_{3}$ mixing was known to better than $50 \%$ (at $68 \%$ confidence). As shown in Figure 9, the measured deposition velocities are all less than the maximum deposition velocity estimated from the measured turbulence conditions using Eq (8), with a typical ratio for the measured to maximum deposition velocity of approximately 0.5 . This is consistent with some combination of imperfect sticking to leaf surfaces and stomatal resistance to $\mathrm{NH}_{3}$ uptake by the leaves.

\subsection{Transport Model Estimates of $\mathrm{NH}_{3}$ Concentrations}

The map of the estimated surface $\mathrm{NH}_{3}$ fluxes from cattle is shown in Figure 10. Surface fluxes range over several orders of magnitude, reflecting the strong emissions from the Central Valley and low emissions from the mountainous regions of the Sierra Nevada. Figure 10 includes an 
example ensemble of 12-hour particle back-trajectories representing a measurement at BFRS at 1300 hours local time on June $12^{\text {th }}$, 2006. This example shows that some particle tracks sweep backward into the Central Valley where they come into contact with high surface $\mathrm{NH}_{3}$ fluxes.

The predicted $\mathrm{NH}_{3}$ concentrations from the back trajectory simulations are compared with measured $\mathrm{NH}_{3}$ in Figure 11. Measured $\mathrm{NH}_{3}$ is generally a factor of $\sim 2$ higher than $\mathrm{NH}_{3}$ predicted with deposition and a factor of $\sim 2$ less than $\mathrm{NH}_{3}$ predicted without deposition. The temporal variations in predicted and measured $\mathrm{NH}_{3}$ mixing ratios match reasonably well. This is likely because the large variations are caused by variations in the amount of air reaching BFRS from areas in the Central Valley where $\mathrm{NH}_{3}$ fluxes are highest.

\section{Conclusions}

We performed an exploratory study of $\mathrm{NH}_{3}$ mixing ratios and fluxes at Blodgett Forest during June, 2006. The 1 hour averaged $\mathrm{NH}_{3}$ mixing ratios ranged from non-detection $(<0.2 \mathrm{ppb})$ to about $2 \mathrm{ppb}$, typical of a low-background site removed from significant sources. The diurnal variations were consistent with upslope flows bringing air with higher $\mathrm{NH}_{3}$ to the site during the day. The observed $\mathrm{NH}_{3}$ mixing ratios were not sufficient to support $\mathrm{NH}_{4} \mathrm{NO}_{3}$ aerosol in equilibrium with gas phase $\mathrm{NH}_{3}$ assuming $\mathrm{HNO}_{3}$ was similar to that observed at the site previously. $\mathrm{NH}_{3}$ fluxes, measured using the eddy covariance method, were generally small or negative, consistent dry deposition to the vegetation and no significant net emission. Calculated deposition velocities were generally about half of the maximum expected for deposition to a canopy with aerodynamic and leaf boundary layer resistance but no resistance to leaf uptake (perfect sticking to leaves). This is not surprising given the nitrogen poor soils in the Sierra foothills. Last, we predicted $\mathrm{NH}_{3}$ at BFRS by combining a simple $\mathrm{NH}_{3}$ emission inventory that considered only emissions from cows (dairy and meat) with a particle back-trajectory model. Measured and predicted $\mathrm{NH}_{3}$ concentrations showed substantially similar temporal patterns over synoptic time periods. Predictions with and without $\mathrm{NH}_{3}$ deposition bracketed the measured $\mathrm{NH}_{3}$ mixing ratios. On the basis of these measurements, we conclude that $\mathrm{NH}_{3}$ from the Central Valley had a small but measurable effect on $\mathrm{NH}_{3}$ mixing ratios at the BFRS site during the short period of this study, but further measurements would be necessary to determine the whether the same patterns prevail over longer periods, particularly between different seasons. 


\section{Acknowledgements}

367 We acknowledge Benet Duncan, Dennis Dibartolomeo, and Joshua Hatch for assistance in

368 construction of the instrument packaging and thermal control systems, Mark Zahniser and David

369 Nelson for technical advice on the use of the $\mathrm{NH}_{3}$ spectrometer. Allen Goldstein generously

370 shared the research infrastructure at BFRS, while David and Sheryl Rambeau provided

371 invaluable assistance with arrangements for field work at BFRS. Steven Kohl of the Desert

372 Research Institute prepared the filter sampler and performed the analysis of the integrated $\mathrm{NH}_{3}$

373 mixing ratios. John Lin generously provided the STILT model for the atmospheric transport

374 simulations. The NOAA Air Resources Laboratory (ARL) provided the assimilated meteorology

375 used to drive STILT. Nancy Brown, Ron Cohen, Delphine Farmer, Martin Gallagher, Ash

376 Lashgari, Melissa Lunden and Tom Ryerson provided valuable advice and discussion. This

377 work was supported by the California Air Resources Board and by the Laboratory Directors

378 Research and Development Program at the Lawrence Berkeley National Laboratory. 


\section{$\underline{\text { 6. References }}$}

Baldocchi, D. D., B. B. Hicks and T. P. Meyers (1988). Measuring Biosphere-Atmosphere Exchanges of Biologically Related Gases with Micrometeorological Methods. Ecology (Tempe) 69(5): 1331-1340.

Battye, W., V. P. Aneja and P. A. Roelle (2003). Evaluation and improvement of ammonia emissions inventories. Atmospheric Environment 37(27): 3873-3883.

Chow, J. C., L. W. A. Chen, J. G. Watson, D. H. Lowenthal, K. A. Magliano, K. Turkiewicz and D. E. Lehrman (2006). PM2.5 chemical composition and spatiotemporal variability during the California Regional PM10/PM2.5 Air Quality Study (CRPAQS). Journal of Geophysical Research-Atmospheres 111(D10).

Chow, J. C., J. G. Watson, J. L. Bowen, C. A. Frazier, A. W. Gertler, K. K. and D. L. Fung, and L. L. Ashbaugh (1993). A sampling system for reactive species in the western United States. Sampling and Analysis of Airborne Pollutants. E. D. Winegar and L. H. Keith. New York, A.F. Lewis: 209-228.

Dillon, M. B., M. S. Lamanna, G. W. Schade, A. H. Goldstein and R. C. Cohen (2002). Chemical evolution of the Sacramento urban plume: Transport and oxidation - art. no. 4045. Journal of Geophysical Research-Atmospheres 107(D5-D6): 4045.

Draxler, R. R. and G. D. Hess (1998). An overview of the HYSPLIT_4 modeling system for trajectories, dispersion, and deposition. Australian Meteorological Magazine 47: 295-308.

Farmer, D. K., P. J. Wooldridge and R. C. Cohen (2006). Application of thermal-dissociation laser induced fluorescence (TD-LIF) to measurement of HNO3, Sigma alkyl nitrates, Sigma peroxy nitrates, and NO2 fluxes using eddy covariance. Atmospheric Chemistry and Physics 6: 3471-3486.

Fischer, M. L., D. Littlejohn, M. M. Lunden and N. J. Brown (2003). Automated measurements of ammonia and nitric acid in indoor and outdoor air. Environmental Science \& Technology 37(10): 2114-2119.

Foken, T. and B. Wichura (1996). Tools for quality assessment of surface-based flux measurements. Agricultural and Forest Meteorology 78(1-2): 83-105.

Goldstein, A. H., N. E. Hultman, J. M. Fracheboud, M. R. Bauer, J. A. Panek, M. Xu, Y. Qi, A. B. Guenther and W. Baugh (2000). Effects of climate variability on the carbon dioxide, water, and sensible heat fluxes above a ponderosa pine plantation in the Sierra Nevada (CA). Agricultural \& Forest Meteorology 101(2-3): 113-129.

Horii, C. V., J. W. Munger, S. C. Wofsy, M. Zahniser, D. Nelson and J. B. McManus (2004). Fluxes of nitrogen oxides over a temperate deciduous forest. Journal of Geophysical Research-Atmospheres 109(D8).

Kirchstetter, T. W., C. R. Maser and N. J. Brown (2002). Ammonia emisson inventory for the state of Wyoming. Berkeley, CA, E.O. Lawrence Berkeley National Laboratory.

Kurpius, M. R., M. McKay and A. H. Goldstein (2002). Annual ozone deposition to a Sierra Nevada ponderosa pine plantation. Atmospheric Environment 36(28): 4503-4515.

Lin, J. C., C. Gerbig, S. C. Wofsy, A. E. Andrews, B. C. Daube, and B. B. S. C. A. Grainger, P. S. Bakwin, and D. Y. Hollinger (2004). Measuring Fluxes of Trace Gases at Regional Scales by Lagrangian Observations:

Application to the CO2 Budget and Rectification Airborne (COBRA) Study. J. Geophys. Res. 109: doi:10.1029/2004JD004754, 2004. 
Lin, J. C., C. Gerbig, S. C. Wofsy, A. E. Andrews, B. C. Daube, K. J. Davis and C. A. Grainger (2003). A near-field tool for simulating the upstream influence of atmospheric observations: The Stochastic Time-Inverted Lagrangian Transport (STILT) model - art. no. 4493. Journal of Geophysical Research-Atmospheres 108(D16): 4493.

Lunden, M. M., K. L. Revzan, M. L. F. L. Thatcher, D. Littlejohn, S. V. Hering and N. J. Brown (2003). The transformation of outdoor ammonium nitrate aerosols in the indoor environment. Atmospheric Environment 37: 5633-5644.

Malm, W. C., M. L. Pitchford, M. Scruggs, J. F. Sisler, R. Ames, S. Copeland, K. A. Gebhart and D. E. Day (2000). Spatial and Seasonal Patterns and Temporal Variability of Haze and It's Constituents in the United States. Fort Collins, Cooperative Institute for Research in the Atmosphere, Colorado State University.

Murphy, J. G., A. Day, P. A. Cleary, P. J. Wooldridge and R. C. Cohen (2006). Observations of the diurnal and seasonal trends in nitrogen oxides in the western Sierra Nevada. Atmospheric Chemistry and Physics 6: 5321-5338.

NRC (1998). Research priorities for airborne particulate matter. I. Immediate priorities and a long-range research portfolio. Washington, DC, National Academy Press.

NRC (2000). Research priorities for airborne particulate matter. III. Early Research Progress. Washington, DC, National Academy Press.

Potter, C., C. Krauter and S. Klooster (2001). Statewide Inventory Estimates Statewide Inventory Estimates of Ammonia Emissions from of Ammonia Emissions from Native Soils and Chemical Native Soils and Chemical Fertilizers in Fertilizers in California. Sacramento, California Air Resources Board.

Stelson, A. W. and J. H. Seinfeld (1982). Relative-Humidity and Temperature-Dependence of the Ammonium-Nitrate Dissociation-Constant. Atmospheric Environment 16(5): 983-992.

Tarnay, L., A. W. Gertler, R. R. Blank and G. E. Taylor (2001). Preliminary measurements of summer nitric acid and ammonia concentrations in the Lake Tahoe Basin air-shed: implications for dry deposition of atmospheric nitrogen. Environmental Pollution 113(2): 145-153.

Wesely, M. L. (1989). Parameterization of Surface Resistances to Gaseous Dry Deposition in RegionalScale Numerical-Models. Atmospheric Environment 23(6): 1293-1304.

Zahniser, M. S. (2003). Urban Ammonia Source Characterization Using Infrared Quantum Cascade Laser Spectroscopy. National Atmospheric Deposition Program (NADP) Meeting, Potomac, MD.

Zhang, Q., J. J. Carroll, A. J. Dixon and C. Anastasio (2002). Aircraft measurements of nitrogen and phosphorus in and around the Lake Tahoe Basin: Implications for possible sources of atmospheric pollutants to Lake Tahoe. Environmental Science \& Technology 36(23): 4981-4989. 
$456 \quad \underline{7 .}$ Tables

457 Table 1. Cattle stocking, area, and estimated $\mathrm{NH}_{3}$ flux by county.

\begin{tabular}{|c|c|c|c|c|c|}
\hline County & $\begin{array}{l}\text { Beef } \\
\text { Cows }\end{array}$ & $\begin{array}{l}\text { Dairy } \\
\text { Cows }\end{array}$ & $\begin{array}{l}\text { Other } \\
\text { Cattle }\end{array}$ & $\begin{array}{l}\text { area } \\
\left(\mathrm{km}^{2}\right)\end{array}$ & $\underset{\left.\text { (ng } \mathrm{NH}_{3} \mathrm{~m}^{-2} \mathrm{~s}^{-1}\right)}{\text { ) }}$ \\
\hline Alameda & 9401 & 6 & 10405 & 1888 & 8 \\
\hline Alpine & 1560 & 0 & 551 & 1891 & 1 \\
\hline Amador & 10112 & 20 & 9104 & 1518 & 9 \\
\hline Butte & 8979 & 1261 & 9191 & 4197 & 4 \\
\hline Calaveras & 14390 & 222 & 12878 & 2611 & 8 \\
\hline Colusa & 0 & 0 & 7957 & 2946 & 2 \\
\hline Contra Costa & 0 & 0 & 11596 & 1843 & 5 \\
\hline Del Norte & 1018 & 4703 & 4154 & 2580 & 5 \\
\hline El Dorado & 4115 & 9 & 3551 & 4380 & 1 \\
\hline Fresno & 23422 & 90550 & 282547 & 15265 & 28 \\
\hline Glenn & 17438 & 17304 & 30655 & 3366 & 22 \\
\hline Humboldt & 22333 & 16732 & 24041 & 9146 & 8 \\
\hline Imperial & 0 & 0 & 386634 & 10687 & 27 \\
\hline Inyo & 0 & 0 & 8278 & 26120 & 0 \\
\hline Kern & 36779 & 74708 & 148553 & 20841 & 14 \\
\hline Kings & 5130 & 138292 & 126108 & 3561 & 111 \\
\hline Lake & 4764 & 4 & 4378 & 3220 & 2 \\
\hline Lassen & 25381 & 38 & 23905 & 11667 & 3 \\
\hline Los Angeles & 0 & 0 & 2092 & 10396 & 0 \\
\hline Madera & 15723 & 48086 & 82972 & 5468 & 32 \\
\hline Marin & 9105 & 10309 & 15998 & 1331 & 31 \\
\hline Mariposa & 10204 & 245 & 12130 & 3715 & 5 \\
\hline Mendocino & 0 & 0 & 7691 & 8983 & 1 \\
\hline Merced & 29534 & 223303 & 212270 & 4937 & 133 \\
\hline Modoc & 41564 & 14 & 33615 & 10097 & 6 \\
\hline Mono & 2989 & 0 & 2938 & 7794 & 1 \\
\hline Monterey & 25430 & 1606 & 46025 & 8504 & 7 \\
\hline Napa & 4300 & 245 & 3453 & 1930 & 3 \\
\hline Nevada & 3007 & 108 & 1927 & 2451 & 2 \\
\hline Orange & 392 & 0 & 401 & 2021 & 0 \\
\hline Placer & 0 & 0 & 10004 & 3595 & 2 \\
\hline Plumas & 5766 & 7 & 10644 & 6537 & 2 \\
\hline Riverside & 3670 & 90359 & 87042 & 18451 & 14 \\
\hline Sacramento & 16392 & 18337 & 32807 & 2472 & 31 \\
\hline $\begin{array}{l}\text { San Benito } \\
\text { San }\end{array}$ & 14408 & 935 & 24054 & 3556 & 9 \\
\hline Bernardino & 2918 & 158240 & 110185 & 51334 & 8 \\
\hline San Diego & 6363 & 5729 & 13709 & 10752 & 3 \\
\hline San Francisco & 0 & 0 & 0 & 120 & 0 \\
\hline
\end{tabular}




\begin{tabular}{|lrrrcc|} 
San Joaquin & 19629 & 103534 & 95196 & 3582 & 86 \\
San Luis & & & & & \\
Obispo & 38268 & 550 & 44928 & 8459 & 7 \\
San Mateo & 1474 & 6 & 941 & 1150 & 2 \\
Santa Barbara & 19482 & 2669 & 21183 & 7007 & 5 \\
Santa Clara & 0 & 0 & 12692 & 3304 & 3 \\
Santa Cruz & 984 & 176 & 2275 & 1140 & 2 \\
Shasta & 16618 & 562 & 11225 & 9690 & 2 \\
Sierra & 3339 & 0 & 3777 & 2441 & 2 \\
Siskiyou & 34750 & 1518 & 28421 & 16094 & 3 \\
Solano & 14560 & 3947 & 26605 & 2123 & 18 \\
Sonoma & 14311 & 31986 & 35301 & 4034 & 26 \\
Stanislaus & 42007 & 162878 & 221060 & 3824 & 142 \\
Sutter & 0 & 0 & 5321 & 1543 & 3 \\
Tehama & 29027 & 5489 & 33679 & 7555 & 8 \\
Trinity & 2671 & 12 & 2252 & 8137 & 0 \\
Tulare & 31171 & 412462 & 456491 & 12349 & 101 \\
Tuolumne & 6855 & 108 & 5288 & 5723 & 2 \\
Ventura & 4357 & 17 & 4544 & 4724 & 1 \\
Yolo & 6773 & 2012 & 8124 & 2594 & 6 \\
Yuba & 7419 & 3325 & 20694 & 1615 & 17 \\
\hline
\end{tabular}

458

459 Table 2. Comparison of $\mathrm{NH}_{3}$ mixing ratios (ppb) from DRI filter samples and averages

\begin{tabular}{|lllll|}
\hline \multicolumn{1}{|c}{ Date time (GMT) } & \multicolumn{2}{c}{ Filter } & \multicolumn{2}{c|}{ LBNL } \\
\hline 24/06/2006 7:00 & 1.46 & $(0.05)$ & 0.74 & $(0.28)$ \\
24/06/2006 19:00 & 1.55 & $(0.05)$ & 0.36 & $(0.13)$ \\
25/06/2006 7:00 & 0.90 & $(0.12)$ & 0.56 & $(0.32)$ \\
25/06/2006 19:00 & 0.58 & $(0.14)$ & 0.91 & $(0.30)$ \\
\hline
\end{tabular}




\section{Figure Captions}

461 Fig 1. Satellite mosiac image showing the Blodgett Forest Research Station in the 462 forested western foothills of the central Sierra Nevada of California, and the mixed use 463 (agricultural and urban) areas of the nearby Sacramento Valley area.

464 Fig 2. Schematic illustration of the air sampling manifold with critical orifice flow inlet and

465 air filter. Automated instrument zero and span calibrations are performed by

466 periodically flowing $\mathrm{N}_{2}$ into inlet, either without or with the addition of $\mathrm{NH}_{3}$ from a

467 permeation tube source.

468 Fig 3. Time series of $\mathrm{NH}_{3}$ mixing ratio showing transient decay following removal of $\mathrm{NH}_{3}$ span 469 gas from zero air flow to instrument inlet.

470 Fig 4. Hourly $\mathrm{NH}_{3}$ mixing ratios measured at Blodgett Forest in June, 2006. $\mathrm{NH}_{3}$ data

471 from the laser-spectrometer (black symbols) are averaged into 12 hour bins for

472 comparison with integrating filter samples (blue symbols) collected with a sampling

473 system provided by the Desert Research Institute.

474 Fig 5. Mean diurnal variation in surface $\mathrm{NH}_{3}$ mixing ratio from June $11^{\text {th }}$ to $26^{\text {th }}, 2006$.

475 Fig 6. Comparison of $\mathrm{NH}_{3}$ mixing ratio (black) and aerosol-gas equilibrium partitioning

476 coefficient, $\mathrm{Kp}$ (red), indicating minimum product of gas phase $\mathrm{NH}_{3}$ and $\mathrm{HNO}_{3}$ mixing

477 ratios necessary for $\mathrm{NH}_{4} \mathrm{NO}_{3}$ aerosol to be found in equilibrium with gas phase

478 constituents. 
479 Figure 7. Power spectra of covariance in vertical wind speed with sonic temperature, 480 w' $\mathrm{T}^{\prime}$, smoothed sonic temperature, w' $\mathrm{T}^{\prime}$ sm, and fluctuations in $\mathrm{NH}_{3}$ mixing ratio,

481 w' $\mathrm{NH}_{3}$. The straight line in upper right shows $-4 / 3$ slope expected for fluctuation

482 spectra in an inertial sublayer.

483 Figure 8. Eddy covariance measurement of $\mathrm{NH}_{3}$ flux for all time points (crosses) and for those 484 passing quality control criteria for use in calculating deposition velocities (filled squares).

485 Figure 9. Scatter plot comparison of measured deposition velocity, $\mathrm{v}_{\mathrm{d}}$, and maximum deposition 486 velocity in the case that all molecules reaching the leaf surface are absorbed, $\mathrm{v}_{\mathrm{dmax}}$.

487 Figure 10. Figure 10. Map of California showing estimated $\mathrm{NH}_{3}$ emissions ( $\mathrm{ng} \mathrm{NH}_{3} \mathrm{~m}^{-2} \mathrm{~s}^{-1}$ ) and 488 an example 12hr back trajectory calculation of showing particles converging at BFRS at midday 489 on June $12^{\text {th }}, 2006$.

490 Figure 11. Measured hourly $\mathrm{NH}_{3}$ mixing ratios from LBNL system (black points), DRI 12 hour 491 integrated sampler results (blue points), and predicted $\mathrm{NH}_{3}$ mixing ratios predicted from the back 492 trajectory calculations and cattle-only $\mathrm{NH}_{3}$ emission inventory. Predicted $\mathrm{NH}_{3}$ is scaled to fit on 493 plot so that $\mathrm{NH}_{3}$ predicted without deposition (red line) is scaled by a factor of 0.5 , while $\mathrm{NH}_{3}$ 494 predicted with deposition (green line) is scaled by a factor of 2 .

\section{9. Figures}

496 


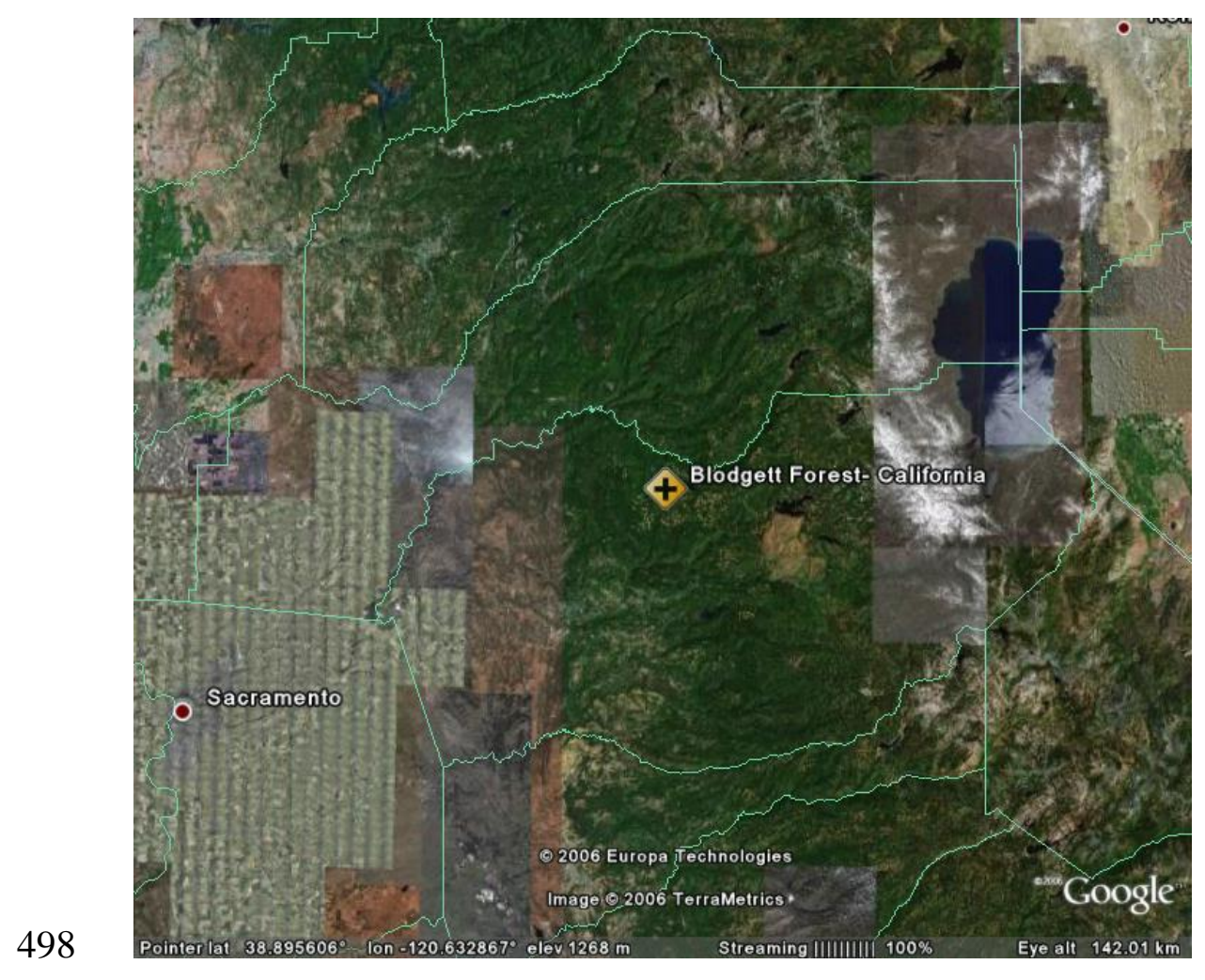

499 Fig 1. Satellite mosiac image showing the Blodgett Forest Research Station in the 500 forested Western foothills of the central Sierra Nevada range of California, and the 501 mixed use (agricultural and urban) areas of the nearby Sacramento Valley area. 


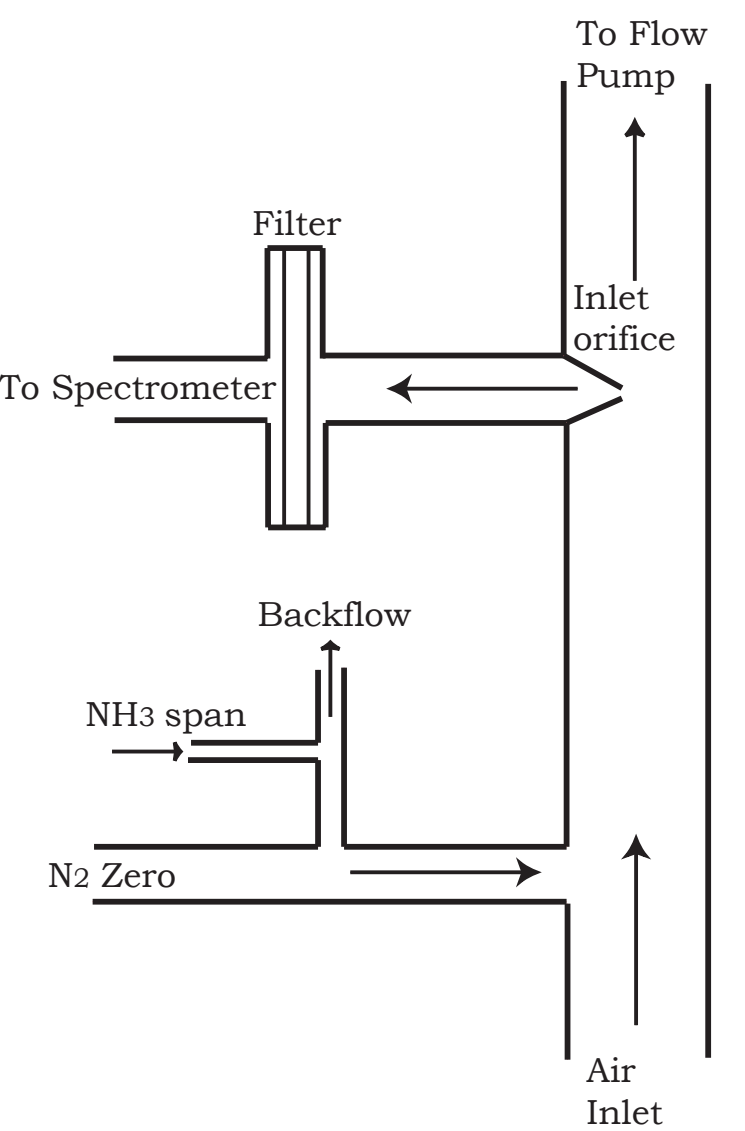

504 Fig 2. Schematic illustration of the air sampling manifold with critical orifice flow inlet and

505 air filter. Automated instrument zero and span calibrations are performed by

506 periodically flowing $\mathrm{N}_{2}$ into inlet, either without or with the addition of $\mathrm{NH}_{3}$ from a

507 permeation tube source.

508 


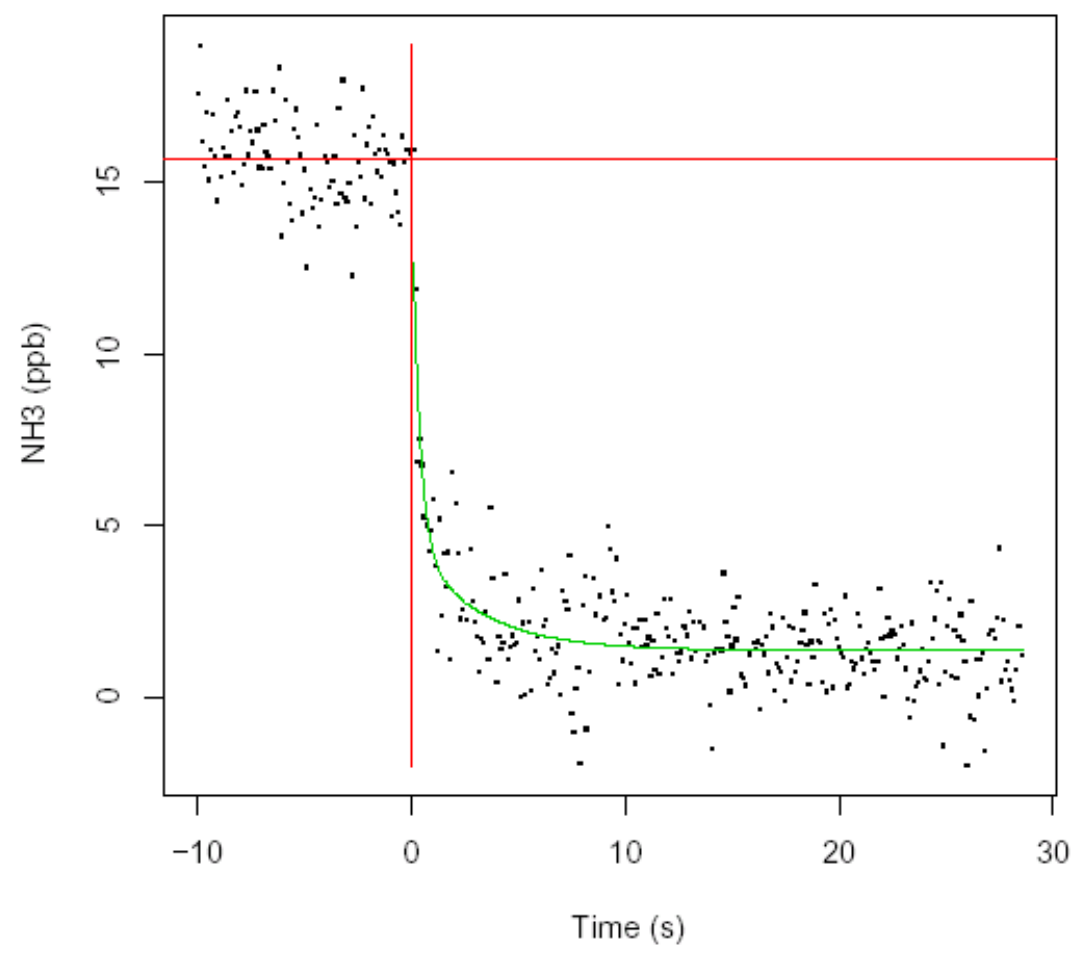

511 Fig 3. Time series of $\mathrm{NH}_{3}$ mixing ratio showing transient decay following removal of $\mathrm{NH}_{3}$ span 512 gas from zero air flow to instrument inlet. 


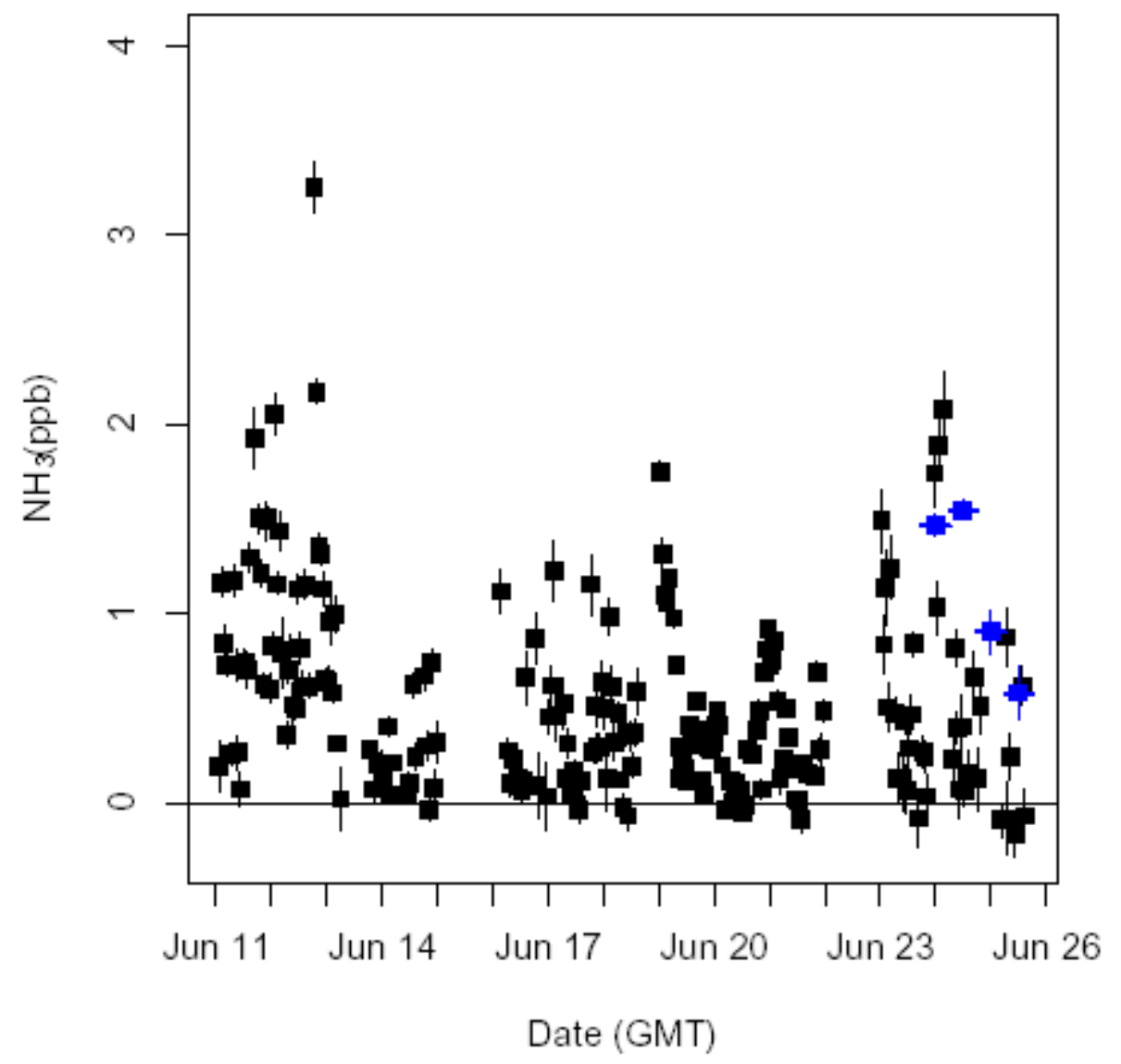

516 Fig 4. Hourly $\mathrm{NH}_{3}$ mixing ratios measured at Blodgett Forest in June, 2006. $\mathrm{NH}_{3}$ data from the

517 laser-spectrometer (black symbols) are averaged into 12 hour bins for comparison with

518 integrating filter samples (blue symbols) collected with a sampling system provided by the 519 Desert Research Institute.

520 


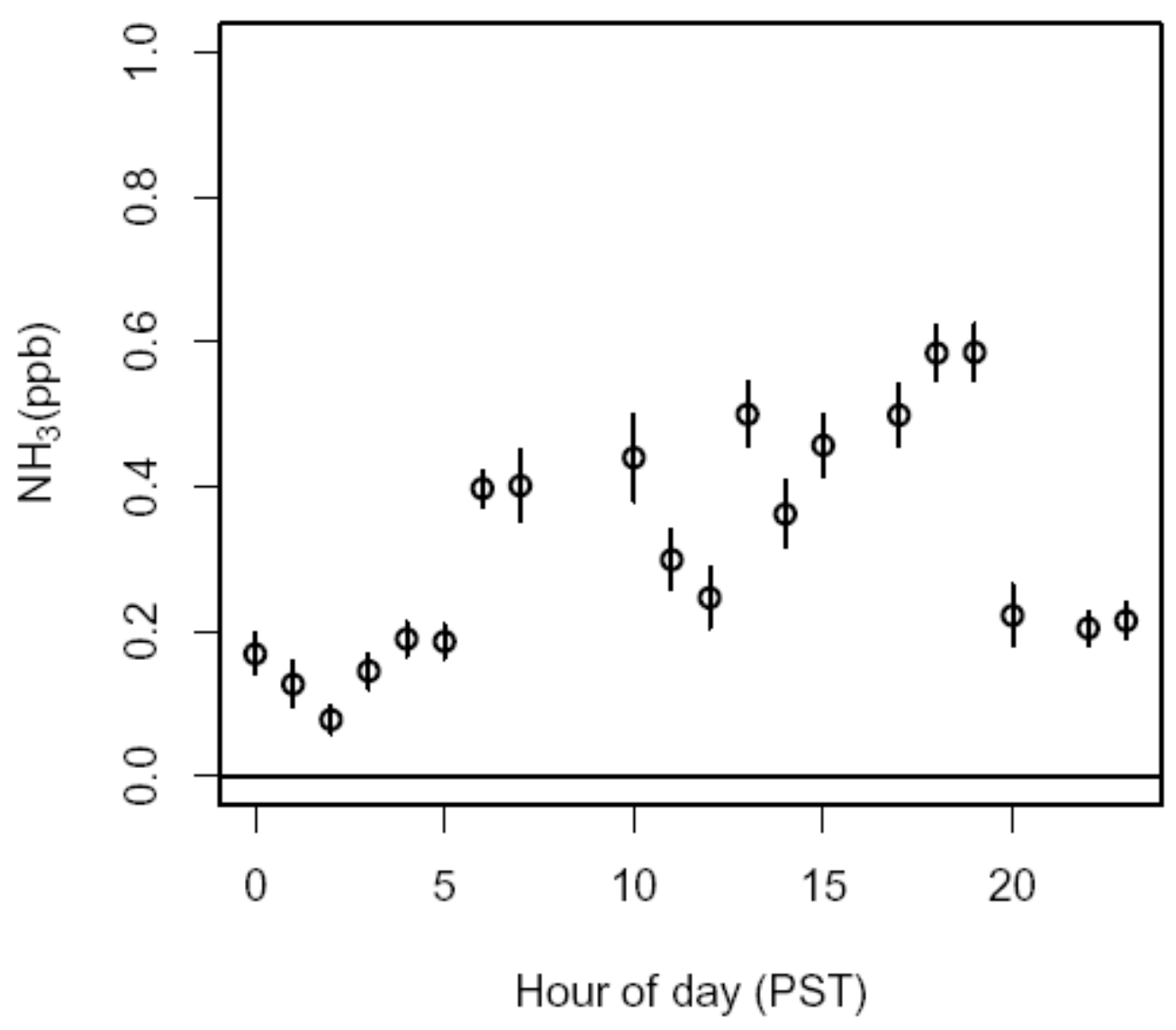

522 Fig 5. Mean diurnal variation in surface $\mathrm{NH}_{3}$ mixing ratio from June $11^{\text {th }}$ to $26^{\text {th }}, 2006$. 


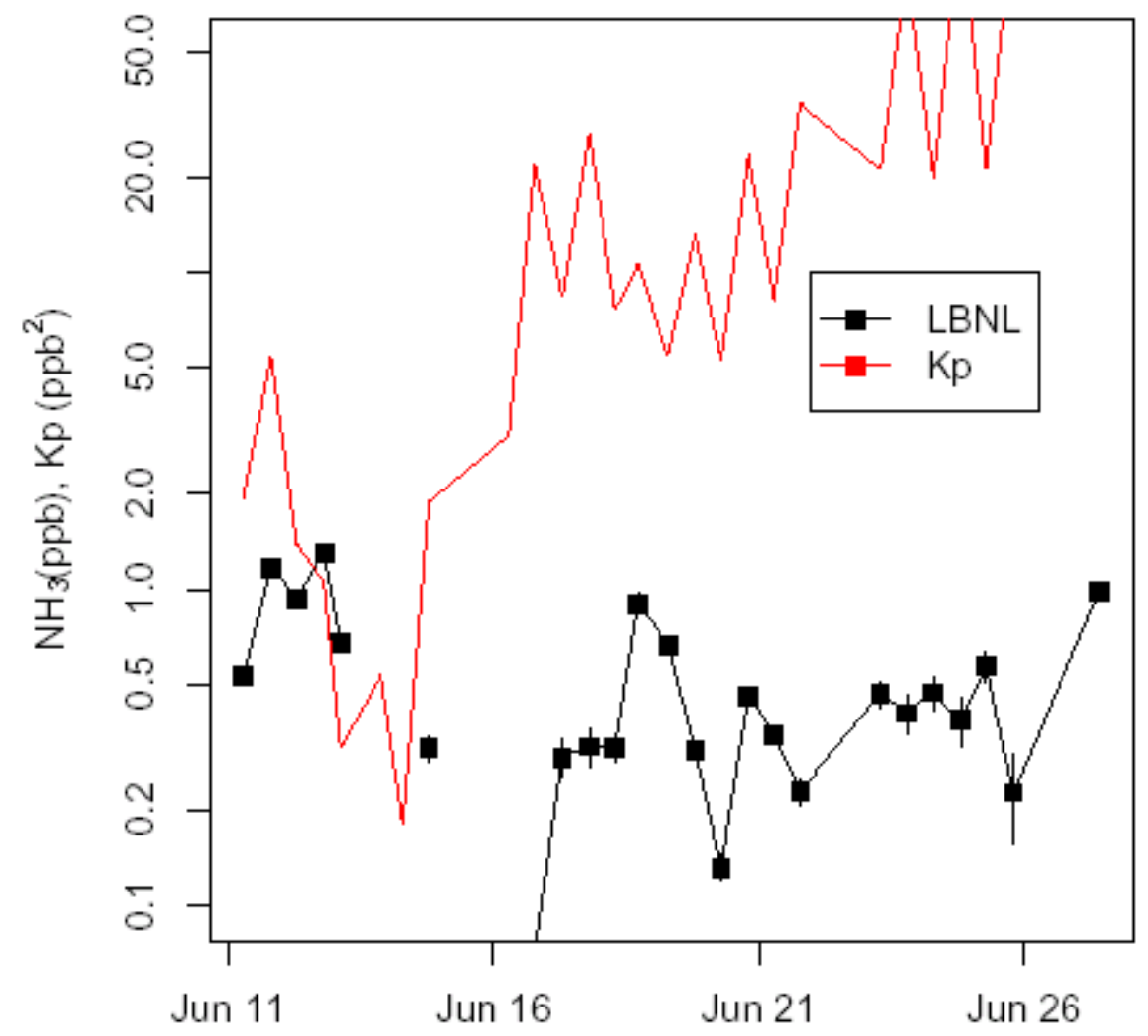

523

524 Fig 6. Comparison of $\mathrm{NH}_{3}$ mixing ratio (black) and aerosol-gas equilibrium partitioning

525 coefficient, $\mathrm{Kp}(\mathrm{red})$, indicating minimum product of gas phase $\mathrm{NH}_{3}$ and $\mathrm{HNO}_{3}$ mixing

526 ratios necessary for $\mathrm{NH}_{4} \mathrm{NO}_{3}$ aerosol to be found in equilibrium with gas phase

527 constituents.

528 


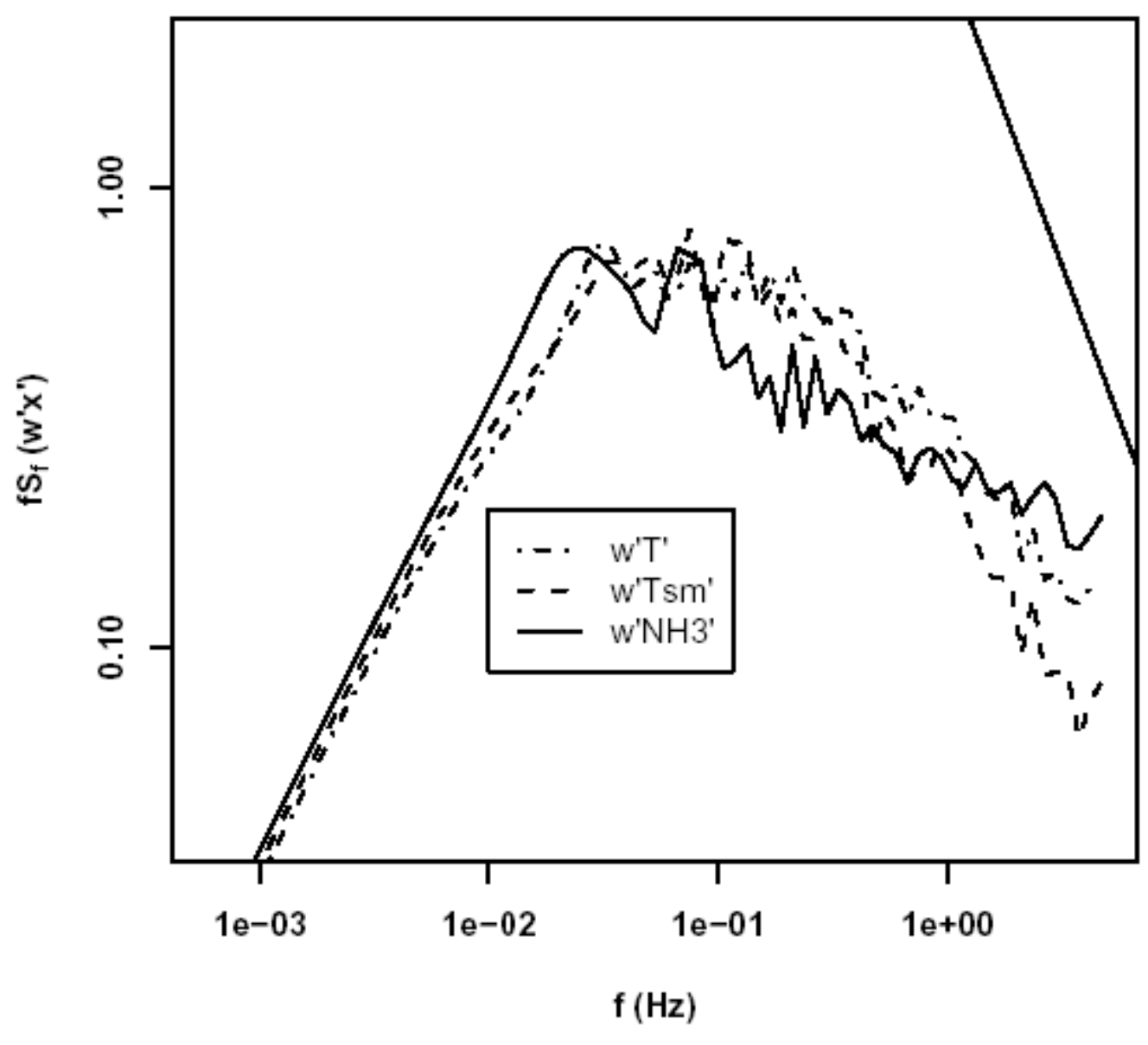

530 Figure 7. Power spectra of covariance in vertical wind speed with sonic temperature,

531 w' $\mathrm{T}^{\prime}$, smoothed sonic temperature, $\mathrm{w}^{\prime} \mathrm{T}^{\prime}$ sm, and fluctuations in $\mathrm{NH}_{3}$ mixing ratio,

532 w' $\mathrm{NH}_{3}$ '. The straight line in upper right shows $-4 / 3$ slope expected for fluctuation

533 spectra in an inertial sublayer. 


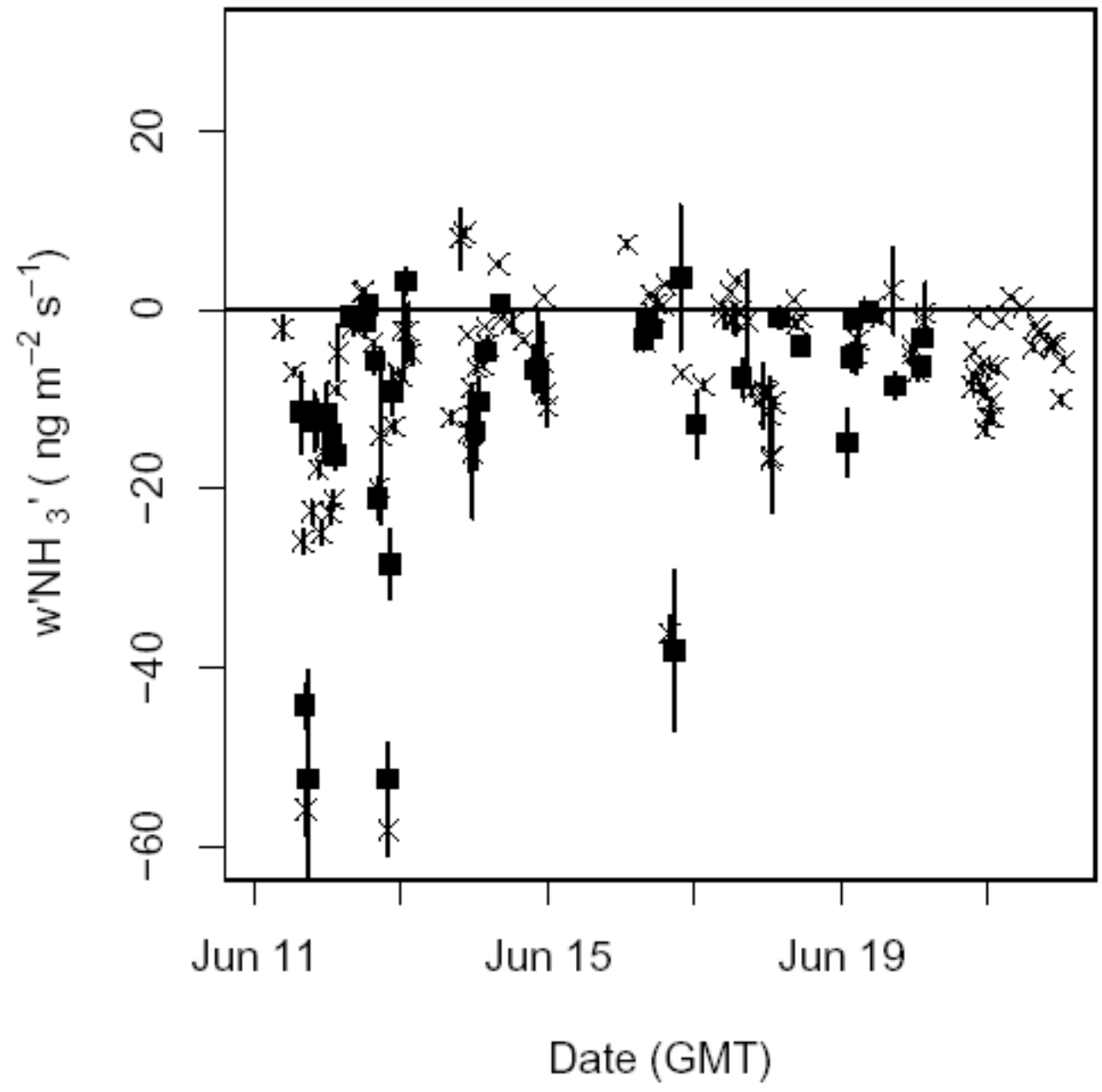

536 Figure 8. Eddy covariance measurement of $\mathrm{NH}_{3}$ flux for all time points (crosses) and for those 537 passing quality control criteria for use in calculating deposition velocities (filled squares). 


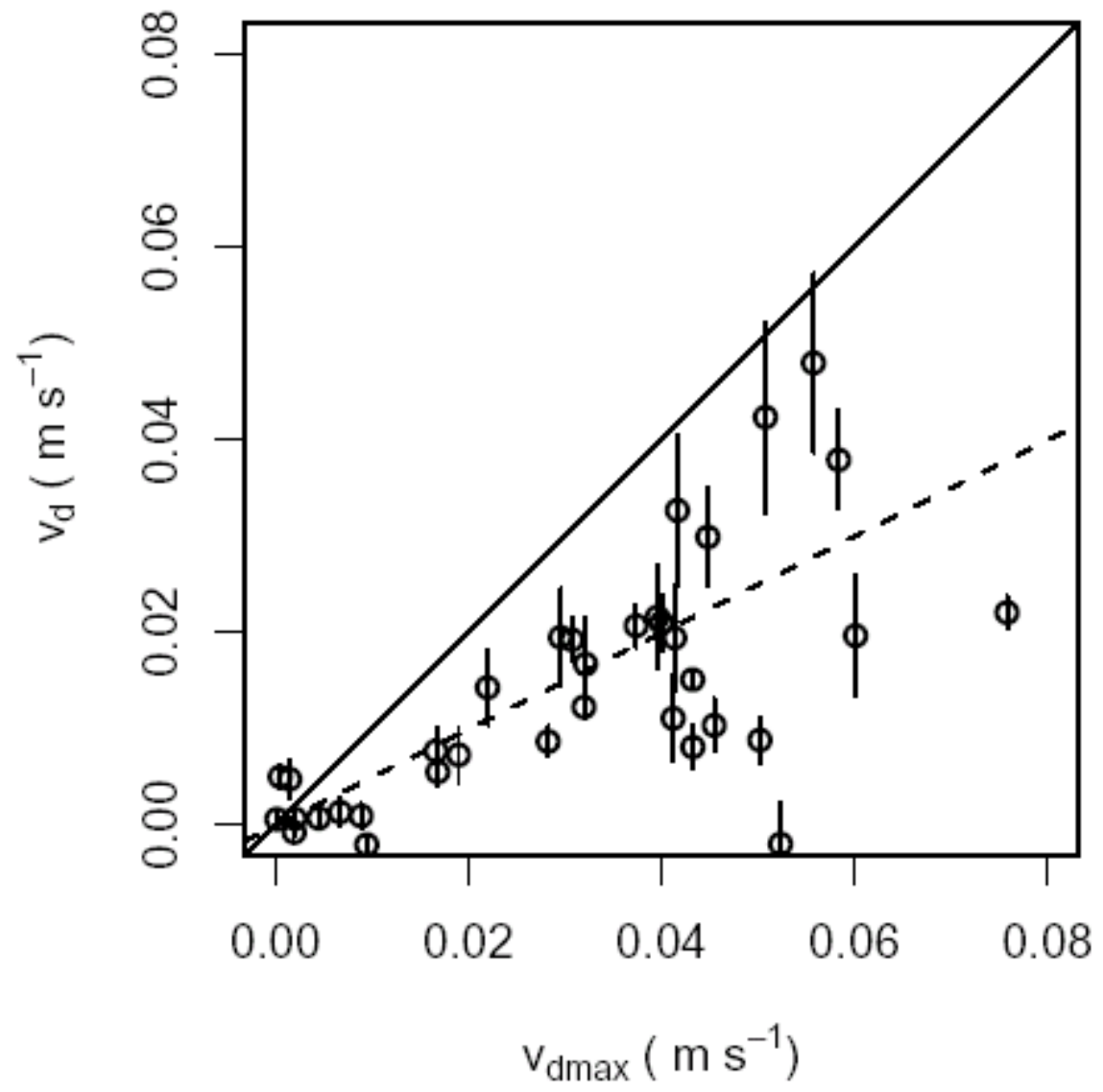

541 Figure 9. Scatter plot comparison of measured deposition velocity, $\mathrm{v}_{\mathrm{d}}$, and maximum deposition 542 velocity in the case that all molecules reaching the leaf surface are absorbed, $\mathrm{v}_{\mathrm{dmax}}$. 


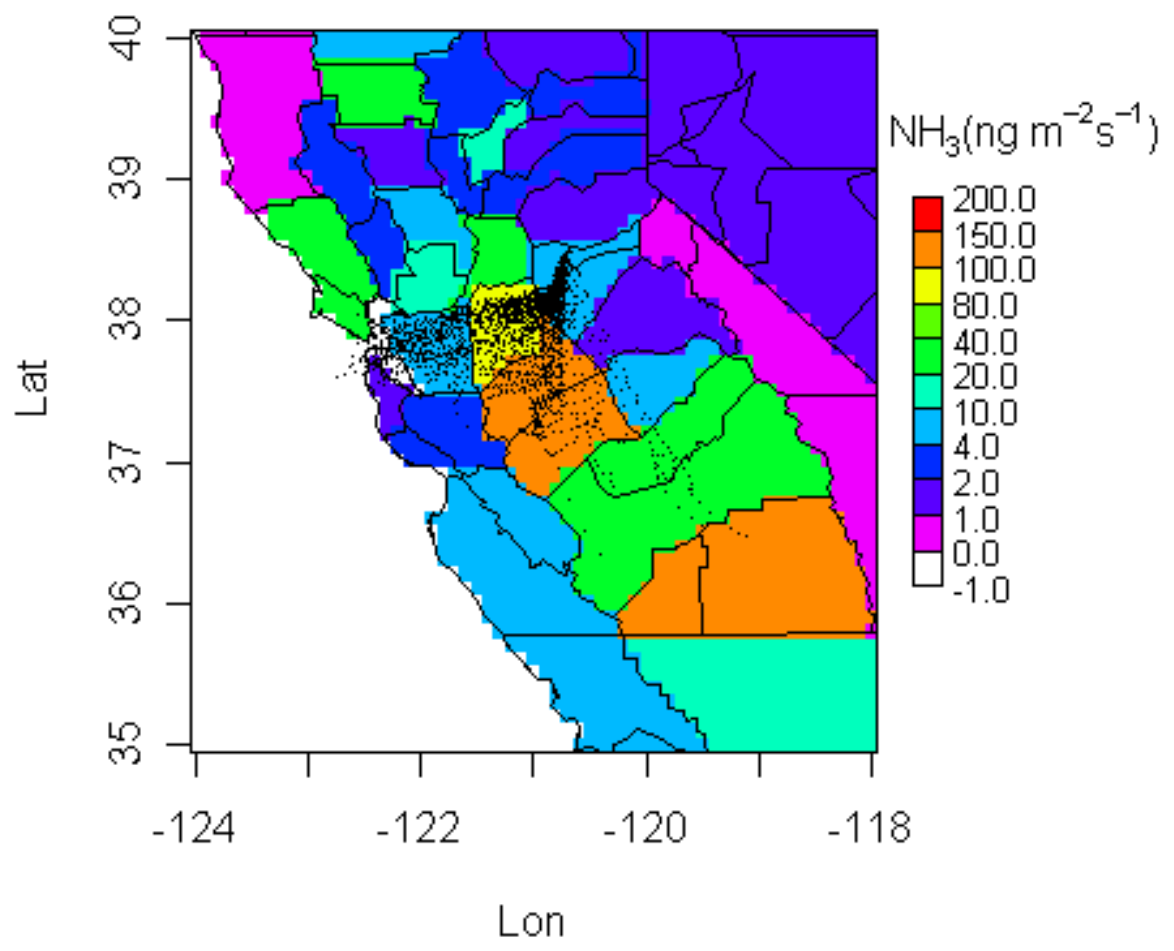

544

545 Figure 10. Map of California showing estimated $\mathrm{NH}_{3}$ emissions (ng $\mathrm{NH}_{3} \mathrm{~m}^{-2} \mathrm{~s}^{-1}$ ) and an 546 example $12 \mathrm{hr}$ back trajectory calculation of showing particles converging at BFRS at midday on 547 June $12^{\text {th }}, 2006$.

548

549 


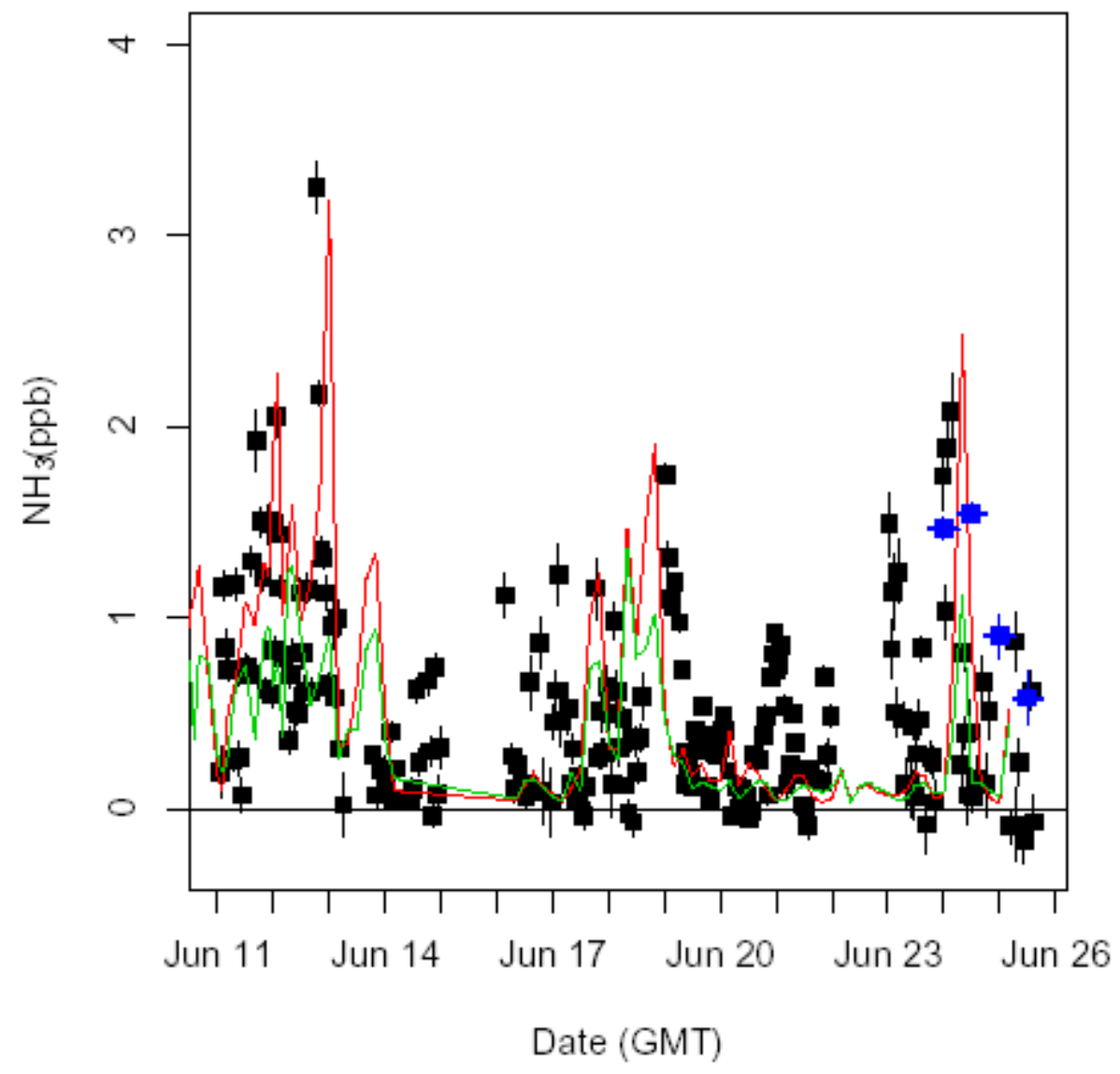

550

551 Figure 11. Measured hourly $\mathrm{NH}_{3}$ mixing ratios from LBNL system (black points), DRI 12 hour 552 integrated sampler results (blue points), and predicted $\mathrm{NH}_{3}$ mixing ratios predicted from the back 553 trajectory calculations and cattle-only $\mathrm{NH}_{3}$ emission inventory. Predicted $\mathrm{NH}_{3}$ is scaled to fit on 554 plot so that $\mathrm{NH}_{3}$ predicted without deposition (red line) is scaled by a factor of 0.5 , while $\mathrm{NH}_{3}$ 555 predicted with deposition (green line) is scaled by a factor of 2. 